\title{
Etiology of Sweet Potato Chlorotic Dwarf Disease in Argentina
}

\author{
L. Di Feo, S. F. Nome, and E. Biderbost, Instituto de Fitopatología y Fisiología Vegetal (IFFIVE-INTA), Camino 60 \\ Cuadras, Km 5 1/2 (5119), Córdoba, Argentina; S. Fuentes and L. F. Salazar, International Potato Center (CIP), Apartado \\ 1558, Lima, Peru
}

\begin{abstract}
Di Feo, L., Nome, S. F., Biderbost, E., Fuentes, S., and Salazar, L. F. 2000. Etiology of sweet potato chlorotic dwarf disease in Argentina. Plant Dis. 84:35-39.

Chlorotic dwarf (CD), the most important disease in the sweet potato-producing regions of Argentina, is caused by the synergistic combination of two aphid-transmitted potyviruses with a whitefly-transmitted crinivirus. Sweet potato feathery mottle virus, sweet potato mild speckling virus, and a crinivirus (serologically related to sweet potato chlorotic stunt virus) were associated with $\mathrm{CD}$. The synergistic combination of these three viruses reproduced the disease.
\end{abstract}

Additional keywords: Bemisia tabaci, Myzus persicae, sweet potato sunken vein virus, synergistic virus interactions

There are approximately fifteen viruses known to affect sweet potatoes (Ipomoea batatas (L.) Lam.) $(3,5,27)$. Sweet potato feathery mottle potyvirus (SPFMV) (26) is the most common virus found wherever sweet potatoes are cultivated, causing variable symptoms and damage to crops $(5,23,25$, 27). SPFMV in synergistic combination with a whitefly-transmitted crinivirus (identified as sweet potato sunken vein virus [SPSVV] in Israel $[6,17]$ and sweet potato chlorotic stunt crinivirus [SPCSV] in Nigeria [36]) is known to cause sweet potato virus disease (SPVD) in Africa (14-16,33, $34,37,39)$. SPCSV has been recommended as the preferred name (40) for the crinivirus found in SPVD. SPSVV reported from Uganda (20) apparently is a different strain of SPCSV.

A disease known as batata crespa (curly sweet potato) in Argentina, caused by sweet potato vein mosaic potyvirus (SPVMV) (28), had devastated cv. Criolla Amarilla by 1970 . Yield reductions of $84 \%$ in the cultivar were reported (29). Later, SPFMV again was detected in affected plants of the same cultivar (30). Because of batata crespa, a new cultivar (Morada-INTA, tolerant to both SPFMV and SPVMV) was adopted by Argentinean farmers in 1978. The cultivar is now grown on more than $90 \%$ of the area planted to sweet potato in Argentina. Since 1984, Morada-INTA has been affected by a severe disease, termed chlorotic dwarf (CD) based on symptoms in infected plants (9). $\mathrm{CD}$-affected plants are stunted, and their

Corresponding author: L. F. Salazar

E-mail: 1.salazar@cgiar.org

Accepted for publication 30 August 1999.

Publication no. D-1999-1025-01R

(C) 2000 The American Phytopathological Society leaves show severe mosaic, blisters, distortion, and reduced leaf area. Symptoms become more severe as the number of vegetative propagations after infection increases (2). CD disease causes yield reductions of up to $80 \%$ (8). Previous serological (enzymelinked immunosorbent assay [ELISA]) work demonstrated that SPFMV was always present in affected plants. However, immunosorbent electron microscopy and decoration (ISEM-D) with SPFMV antiserum indicated that other viruses (undecorated flexuous particles) also were present. Later, two viruses serologically related to sweet potato mild speckling virus (SPMSV) and SPCSV were isolated from CD-affected plants. SPMSV has been reported as a new potyvirus based on molecular characterization of its coat protein (1) and is serologically unrelated to five other sweet potato viruses: SPFMV, sweet potato latent (SwPLV), sweet potato mild mottle (SPMMV), sweet potato chlorotic flecks (SPCFV), and C-6 viruses $(3,10,12)$.

In this paper we report on how the viruses involved in $\mathrm{CD}$ disease of sweet potato were isolated and identified and demonstrate that a synergistic combination of three viruses (SPFMV, SPMSV, and SPCSV) reproduced the disease.

\section{MATERIALS AND METHODS}

Source of inoculum. Stem cuttings of cv. Morada-INTA growing in a farmer's field in Cordoba and showing severe CD symptoms (stunting, chlorosis, severe mosaic, and leaf deformation [Fig. 1]) were collected, rooted, and maintained in a growth chamber. These plants were the source of inoculum for the study.

Transmission tests. Sap from test plants was homogenized and diluted in $0.05 \mathrm{M}$ potassium phosphate buffer, $\mathrm{pH} 7.2$, containing $0.2 \%$ sodium sulfite and rubbed on leaves of Nicotiana benthamiana Domin.,
$N$. clevelandii Grey, and Ipomoea setosa Ker.

Apterous aphids from a healthy colony of Myzus persicae Sulz. were reared on Raphanus sativus L. and used for transmission studies. A group of fasted aphids was allowed to probe briefly (one probe) on plants of sweet potato cv. Morada-INTA showing typical CD symptoms (21). One aphid was transferred to each of 50 healthy I. setosa seedlings and allowed to feed for $12 \mathrm{~h}$ before being killed with an aphicide (Pirinicab); the process was repeated once. I. setosa plants from both experiments were tested by nitrocellulose membrane-ELISA (NCM-ELISA) and ISEM-D against SPFMV and SPMSV antisera, respectively (discussed below). In another experiment, the efficiency of aphids in transmitting SPFMV and SPMSV from infected to healthy $I$. setosa was determined. Fasted aphids were given a 5-min virus acquisition access period on infected plants. Two aphids were transferred to each of 50 healthy plants (two repetitions), allowed to feed for $12 \mathrm{~h}$, and killed.

Bemisia tabaci Gennadius reared on poinsettia (Euphorbia pulcherrima Willd.) plants was used for whitefly transmissions. Approximately $100 \mathrm{~B}$. tabaci adults were allowed to feed on a CD-affected plant for $48 \mathrm{~h}$. After the acquisition period, the aphids were transferred to healthy $I$. setosa and $N$. benthamiana and allowed to feed for $48 \mathrm{~h}$ (13).

The viruses isolated through aphid and whitefly transmission were serologically tested for other flexuous sweet potato viruses (SwPLV, SPMMV, SPCFV, and C-6).

Virus purification. At the beginning of the research, viruses from CD-affected plants (mixture of SPFMV, SPMSV, and SPCSV) were purified by the method reported by Cohen et al. (7), with some modifications. Leaves of cv. Morada-INTA were homogenized $(1: 2, \mathrm{wt} / \mathrm{vol})$ with $0.5 \mathrm{M}$ borate buffer, $\mathrm{pH}$ 8.0, containing $0.01 \mathrm{M}$ EDTA and $0.05 \%$ thioglycolic acid. After mixing the homogenate with 1 volume of carbon tetrachloride, 1 volume of chloroform was added dropwise, and the mixture was clarified by centrifugation at $10,000 \times g$ for $10 \mathrm{~min}$. The virus was sedimented from the aqueous phase by centrifugation at $90,000 \times g$ for $2 \mathrm{~h}$ through a $25 \%$ sucrose cushion in $0.05 \mathrm{M}$ borate buffer, $\mathrm{pH} 8.0$, containing $0.001 \mathrm{M}$ EDTA. Pellets were resuspended in the same buffer and sedimented through sucrose- $\mathrm{CsCl}$ step gradients $(0$ to $41 \% \mathrm{CsCl}$ in borate buffer containing $20 \%$ sucrose) at $100,000 \times g$ for $5 \mathrm{~h}$ at $8^{\circ} \mathrm{C}$. The virus band was collected 
and dialyzed in $0.05 \mathrm{M}$ borate buffer and further purified through a second $\mathrm{CsCl}$ gradient. After SPFMV and SPMSV were isolated, purification of the viruses was performed with leaves of I. setosa infected with each virus, following essentially the same procedure.
Antisera production and serological tests. Purified virus preparations of $\mathrm{CD}$ (a mixture of three viruses) as well as SPFMV and SPMSV (in Freunds' complete adjuvant) were injected into New Zealand rabbits by multiple intradermal injections and intramuscularly 10 and 30 days later in Freunds'

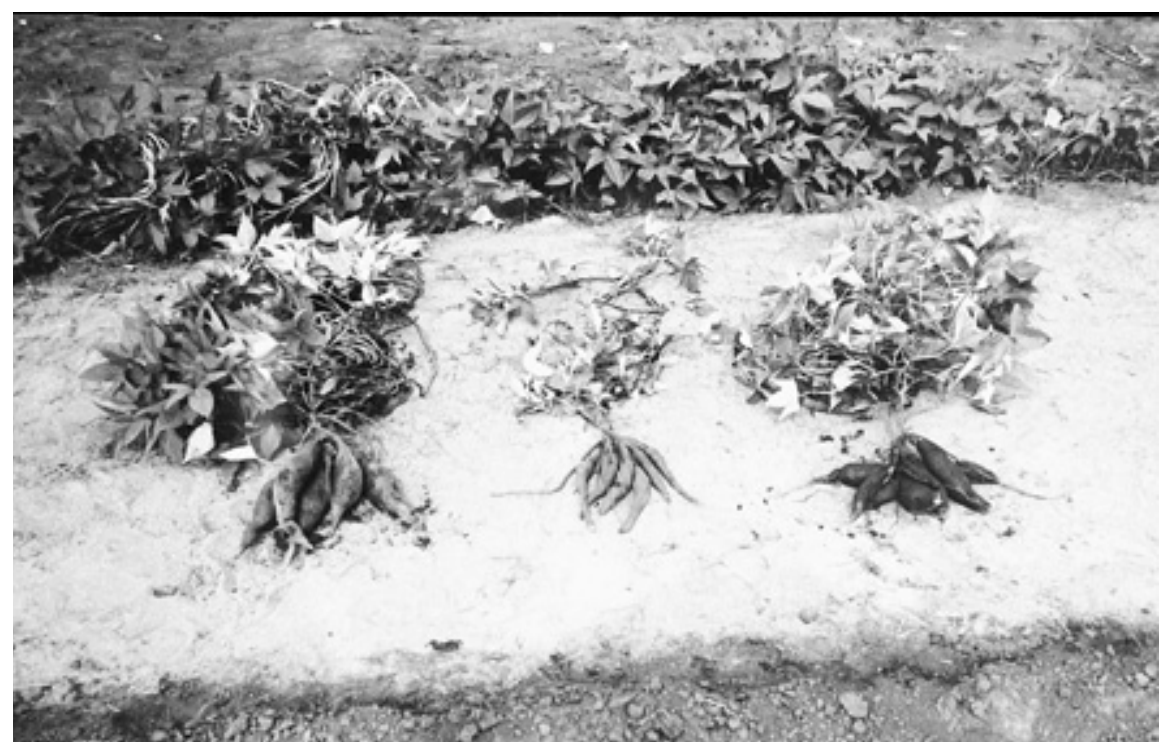

Fig. 1. Chlorotic dwarf-affected sweet potato cv. Morada-INTA showing mild (right) and severe (center) symptoms. Healthy control at left.

Table 1. Detection ${ }^{\mathrm{a}}$ of three viruses in different plants by nitrocellulose membrane enzyme-linked immunosorbent assay with monoclonal antibodies (MAb) for sweet potato chlorotic stunt virus (SPCSV) and polyclonal antibodies (PAb) for sweet potato feathery mottle virus (SPFMV) and sweet potato mild speckling virus (SPMSV)

\begin{tabular}{lccc}
\hline & & Antiserum & \\
\cline { 2 - 4 } Plant $^{\mathbf{b}}$ & SPCSV & SPFMV & SPMSV \\
CD-affected sweet potato cv. Morada-INTA & MAb mix 2 & PAb & PAb \\
Ipomoea setosa with SPFMV & + & + & + \\
Nicotiana benthamiana grafted with CD & - & + & - \\
SPCSV from Israel & + & - & + \\
SPVD from Nigeria & + & + & - \\
I. setos with SPFMV from CD & + & + & - \\
I. setosa with SPMSV from CD & - & - & - \\
I. setosa with SPCSV from CD & - & - & - \\
Healthy cv. Morada-INTA & + & - & - \\
Healthy I. setosa & - & - & - \\
\hline
\end{tabular}

a Positive (+) and negative (-) detection determined by visual assessment.

${ }^{\mathrm{b}} \mathrm{CD}=$ chlorotic dwarf; SPVD = sweet potato virus disease.

Table 2. Detection of viruses in infected sweet potato plants by double-antibody sandwich enzymelinked immunosorbent assay with antisera to partially purified viruses from plants with chlorotic dwarf (CD) disease or infected with sweet potato mild speckling virus (SPMSV) or sweet potato feathery mottle virus (SPFMV)

\begin{tabular}{|c|c|c|c|}
\hline \multirow[b]{2}{*}{ Plant disease } & \multicolumn{3}{|c|}{ Antiserum } \\
\hline & SPMSV & SPFMV & CD \\
\hline SPFMV & $-(0.004)^{\mathrm{a}}$ & $+(0.516)$ & $+(1.714)$ \\
\hline SPMSV & $+(0.303)$ & $-(0.005)$ & $+(0.361)$ \\
\hline $\mathrm{CD}$ & $+(1.731)$ & $+(1.597)$ & $+(2.062)$ \\
\hline SPCSV + SPMSV & $+(1.473)$ & $-(0.004)$ & $+(0.318)$ \\
\hline SPCSV + SPFMV & $-(0.006)$ & $+(0.919)$ & $+(1.938)$ \\
\hline SPCSV + SPMSV+ SPFMV & $+(2.040)$ & $+(0.837)$ & $+(1.999)$ \\
\hline Critical point ${ }^{b}$ & 0.050 & 0.020 & 0.030 \\
\hline
\end{tabular}

${ }^{a} A_{405 \mathrm{~nm}}$ values $90 \mathrm{~min}$ after initiation of reaction. - = negative reaction; + = positive reaction.

${ }^{\mathrm{b}} A_{405 \mathrm{~nm}}$ values of negative control plus three times the standard deviation. incomplete adjuvant. Antisera were used in NCM-ELISA $(22,31)$ and double-antibody sandwich-ELISA (DAS-ELISA), essentially as described by Clark and Adams (4).

A SPFMV monoclonal antiserum (MAb) prepared against isolate SPV-I from the SPVD complex from Nigeria was provided by G. Thotappilly (IITA, Lagos, Nigeria). Polyclonal antiserum for SPCSV was a gift from J. Cohen (Volcani Center, Bet-Dagan, Israel). MAb mixes 1 and 2, which recognize SPCSV from Eastern Africa and Nigeria (as well as from other areas), respectively, was provided by J. Vetten (Federal Biological Research Center, Institute of Biochemistry, Agriculture, and Forestry, Braunschweig, Germany) (38). MAb PTY1, which recognizes cryptotopes in aphid-transmitted potyviruses (19), was obtained from a commercial supplier (Agdia Elkhart, IN).

For ISEM-D, the protocol of Milne and Lesemann (24) was used. For sensitizing grids, antisera was diluted 1:50 in TBS (20 mM Tris base, $500 \mathrm{mM} \mathrm{NaCl}, \mathrm{pH} 7.5$ ) and incubated on the grids for $30 \mathrm{~min}$. Samples from mesophyll tissue adjacent to veins were macerated in TBS containing $0.2 \%$ sodium sulfite $(1: 10, \mathrm{wt} / \mathrm{vol})$ and centrifuged for $5 \mathrm{~min}$ at $2,240 \times \mathrm{g}$. For decoration of virus particles, antisera was diluted 1:10 and incubated for $15 \mathrm{~min}$ on the grids.

Inoculations with three viruses in different combinations. This experiment was designed to determine the virus combination(s) that would reproduce $\mathrm{CD}$ in sweet potato. Scions of $I$. setosa plants infected individually with each of the three isolated viruses (SPFMV, SPMSV, and SPCSV) were double or triple side-grafted onto healthy plants of cv. Morada-INTA and I. setosa. Healthy plants of cv. Morada-INTA grafted with scions from $\mathrm{CD}$-affected plants were used as controls.

All grafted plants were kept in a growth chamber with $16 \mathrm{~h}$ of illumination $(12,000$ lux) at $26^{\circ} \mathrm{C}$ and $8 \mathrm{~h}$ of darkness at $20^{\circ} \mathrm{C}$ and $80 \%$ relative humidity.

DAS-ELISA was used to confirm infection of grafted I. setosa and cv. MoradaINTA with SPFMV and SPMSV. Infection with SPCSV was confirmed by ISEM-D with a polyclonal SPCSV antiserum.

\section{RESULTS}

Isolation of viruses. Two potyviruses were transmitted to healthy $I$. setosa plants by aphids from CD-affected plants. The viruses were SPFMV and SPMSV, and the frequency of isolation from single aphids (M. persicae) was 32 and $26 \%$, respectively. Twenty-eight percent of $I$. setosa plants were infected with both viruses; fourteen percent were not infected with either virus (no symptoms and no serological reaction with any antisera). SPMSV also was isolated, independent of SPFMV, in some sap-inoculated $N$. benthamiana and $N$. clevelandii plants.

Both viruses were maintained in aphidor sap-inoculated I. setosa in insect-proof 
cages in the greenhouse. The efficiency of two aphids per plant in transmitting SPFMV and SPMSV from infected to healthy $I$. setosa was $70 \%$.

Mild mosaic developed in both I. setosa and $N$. benthamiana plants 15 days after transmission of the crinivirus by whiteflies. The presence of this virus and its relationship to SPCSV was shown by ISEM-D.

Virus purification and serology. Viruses were purified in a mixture (SPFMV, SPMSV, and SPCSV) from CD-affected sweet potato plants or separately (SPFMV and SPMSV) from I. setosa infected with each virus alone. Antisera produced in rabbits reached a titer of 1:300,000 for SPMSV, $1: 1,000,000$ for SPFMV, and 1:500,000 for $\mathrm{CD}$ (the three viruses together) in NCMELISA. Viruses detected from different diseased plants are shown in Table 1. CD antiserum reacted with the three viruses isolated from CD-affected plants: strongly with SPFMV, intermediately with SPMSV (Table 2), and weakly with SPCSV (data not shown). When CD antiserum was used to detect SPCSV, it was detected by ISEM$\mathrm{D}$ and NCM-ELISA (after cross-absorption of antiserum with healthy plant proteins).

Table 3. Symptoms induced by three viruses (sweet potato feathery mottle [SPFMV], sweet potato mild speckling [SPMSV], and sweet potato chlorotic stunt [SPCSV]), alone or in combination, in graft-inoculated Ipomoea setosa and sweet potato (I. batatas) cv. Morada-INTA

\begin{tabular}{lll}
\hline Host & Virus & Symptoms \\
\hline I. setosa & SPFMV & $\begin{array}{c}\text { Mild mosaic of first two true leaves, vein clearing; } \\
\text { severe mosaic after fourth leaf, chlorotic spotting; } \\
\text { very mild or no symptoms after eighth leaf } \\
\text { Mild mosaic in first two true leaves }\end{array}$ \\
& Same as SPMSV alone \\
& SPMSV & Mild mosaic \\
& SPFMV + SPMSV & Mosaic, chlorosis, and leaf deformation \\
& SPCSV & Mosaic, chlorosis, severe leaf distortion ( "shoe-lace"), \\
& SPCSV + SPFMV & top necrosis, and death of plants \\
& SPCSV + SPMSV & Vein clearing, mosaic, leaf deformation ("shoe-lace"), \\
& stunting, necrosis, and death of plants \\
& SPCSV + SPFMV + SPMSV & Chlorotic spots only in lower leaves \\
& & Occasional chlorotic speckling in some leaves \\
I. batatas & Chlorotic rings, mosaic, and mild blistering of lower \\
& SPFMV & leaves \\
& SPFMV & Very mild mosaic in old and new leaves \\
& Chlorotic leaves, mild mosaic, reduction of leaf area, \\
& and leaf border curved downward \\
& SPCSV & Severe mosaic of all leaves and vein clearing \\
& SPCSV + SPFMV & Severe mosaic, leaf deformation, vein clearing, and \\
& leaf border curved downward; stunting \\
\hline
\end{tabular}

Isolated SPFMV did not react to the MAb SPFMV SPV-I. SPFMV, but not SPMSV, reacted with MAb PTY1. The isolated crinivirus reacted in NCM-ELISA with SPCSV polyclonal antiserum and MAb mix 2.

Inoculation with SPFMV and SPMSV. Young plants of cv. Morada-INTA were grafted with $I$. setosa scions infected with SPFMV, SPMSV, or both. Plants grafted with SPFMV developed chlorotic mosaic in basal leaves after 20 days (Table 3). In plants grafted with SPMSV, only transient mild speckling was observed in basal leaves. Grafting with the two viruses did not reproduce $\mathrm{CD}$ symptoms, only chlorotic rings, mosaic, and light blistering in basal leaves 20 days after inoculation.

Inoculation with three viruses in different combinations. Symptoms caused by each virus or combination of viruses are shown in Table 3 and Figure 2. Combination of SPCSV with SPFMV, SPMSV, or both caused different degrees of CD severity. The combination of the three viruses induced in I. batatas the most severe symptomatology resembling that of CD-affected plants from the field: severe mosaic, leaf deformation and reduction, and stunting of infected plants.

\section{DISCUSSION}

Because the sweet potato is a vegetatively propagated crop, accumulation and perpetuation of virus diseases is likely to become a major constraint for production $(5-7,14,16$, $27,32,35,39)$. This is especially evident in regions such as Argentina where vector activity is high and sources of virus infections, such as voluntary sweet potato plants and weeds, exist. Previous work has shown

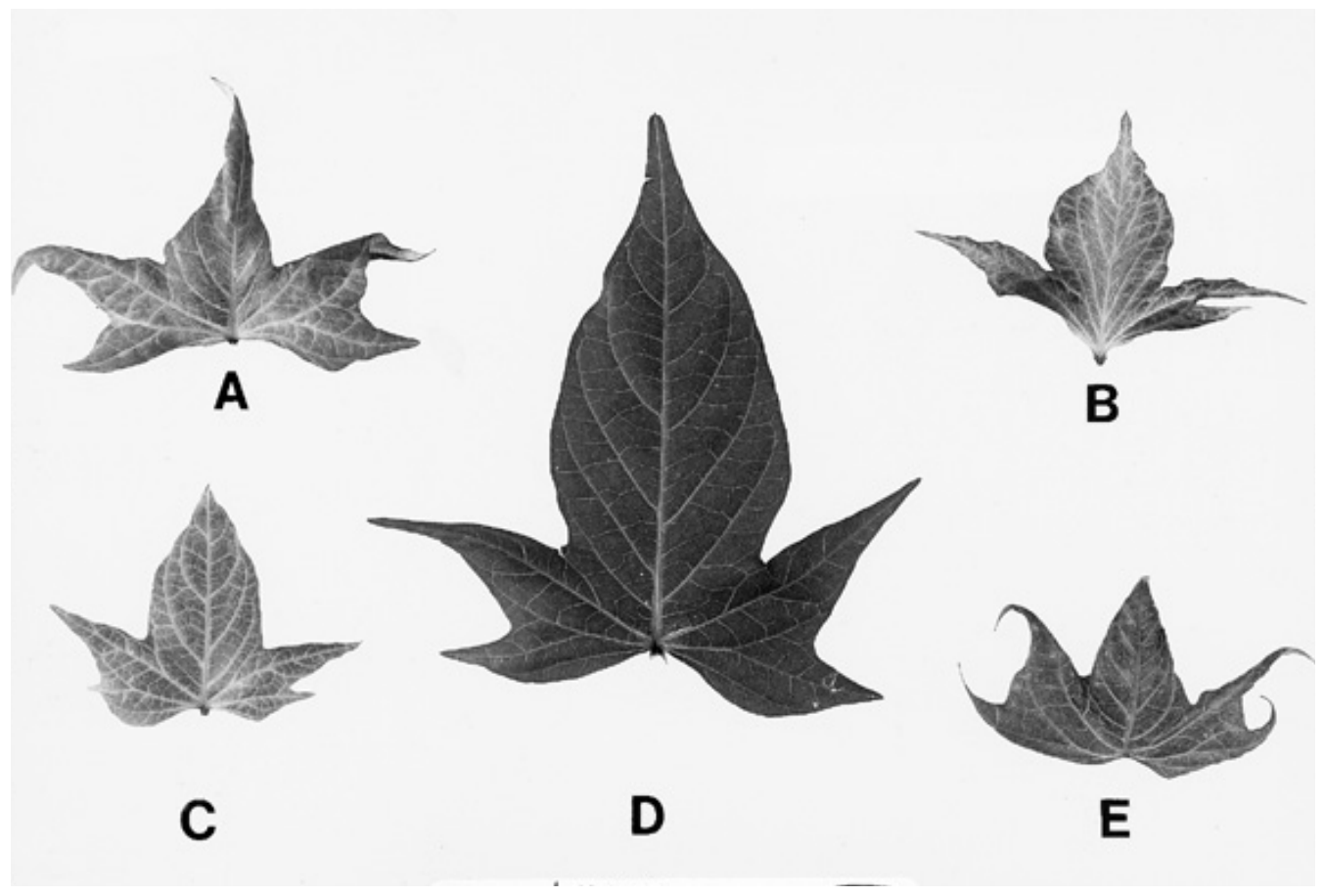

Fig. 2. Leaves of sweet potato cv. Morada-INTA infected with the viruses involved in chlorotic dwarf (CD) disease in different combinations. (A) Sweet potato chlorotic stunt virus (SPCSV) + sweet potato mild speckling virus (SPMSV) + sweet potato feathery mottle virus (SPFMV); (B) field-infected sample showing CD disease; (C) SPCSV + SPMSV; (D) healthy control; and (E) SPCSV + SPFMV. 
that $\mathrm{CD}$ is the most important disease (8) in the sweet potato-producing regions of Argentina. Even though the disease resembles SPVD from Africa, our results indicate that CD disease is caused by the synergistic effect of three viruses, not two as was reported in Africa $(27,33,34,36,39)$. Although the combinations of SPCSV with both SPFMV and SPMSV in dual combinations showed some level of synergistic interaction, symptoms were clearly more severe with a combination of all three viruses than with dual combinations. Because SPFMV hindered isolation of other viruses, we had thought that $\mathrm{CD}$ was caused by an unusual strain of SPFMV. However, we demonstrated that the combination of the three viruses and the different combinations of two of the three viruses account for the variability of CD symptomatology observed in the field. The most severe expression of CD was obtained when SPFMV, SPMSV, and SPCSV infected sweet potato plants simultaneously.

This situation may occur in other regions of the world as well, because all three viruses have been recorded outside Argentina. For instance, SPFMV is found wherever sweet potatoes are grown; SPCSV and its strains are present in several countries (17, 38); and SPMSV is present in Argentina, Peru. and Indonesia (S. Fuentes, unpublished data).

We found that the SPFMV strain from CD-affected plants is different from that reported in Nigeria (SPV-I) $(33,34)$, because it does not infect $N$. benthamiana and is serologically unrelated to SPV-I when a MAb is used. However, a SPFMV strain serologically related to SPV-I has been found in CD-affected plants from other areas of Argentina (data not shown), indicating it is not necessarily a strain-specific combination, at least with SPFMV, that causes CD disease.

The SPCSV strain from CD seems to be different than the strain reported in Nigeria, because the CD-SPCSV caused mild mosaic in I. setosa (and also in sweet potato) and not chlorotic stunt, as was reported for the Nigerian isolate.

The CD disease syndrome (Fig. 1) resembles batata crespa (general chlorosis, vein clearing, mosaic, twisting of leaves, stunting, and reduction in size and number of roots) reported only in Argentina by $1970(5,28)$. However, batata crespa is caused by the infection by a single aphidtransmitted potyvirus (SPVMV). The virus particle size of SPVMV differs from the other two potyviruses present in CD disease: SPVMV $(761 \mathrm{~nm})$ is significantly shorter than SPFMV (868 $\mathrm{nm}$ ) but close in length to SPMSV (790 nm) (data not shown). Because SPVMV and its antiserum are not available for comparison, we do not know its relationship with SPMSV. However, the host range of SPMSV includes species in the Convolvulaceae, Chenopodiaceae, and Solanaceae families (11), while the range for SPVMV is limited to the Convol- vulaceae family (28). As a result, SPVMV induced more severe symptoms in I. setosa (distortion, chlorosis, and size reduction of leaves) than SPMSV (Table 3).

An unusual result found in this study is that although SPFMV and SPMSV are transmitted with equal efficiency $(70 \%)$ by $M$. persicae, only SPFMV reacted with MAb PTY1 (19), which recognizes cryptotopes present in potyviruses transmitted by aphids. However, this is not surprising, because some isolates of other potyviruses (papaya ringspot type $\mathrm{W}$ and peanut mottle) known to be transmitted by aphids also were not recognized by MAb PTY1 (18).

This work emphasizes the need to control $\mathrm{CD}$ by developing large-scale virus-free plant material schemes. Also, it provides the groundwork for development and use of virus-resistant cultivars. In light of our results, resistance to SPCSV would be more appropriate, although extreme resistance to SPFMV also might reduce CD incidence and its deleterious effects on sweet potato.

\section{ACKNOWLEDGMENTS}

The work was conducted at IFFIVE-INTA with the support of CIP, Consejo Nacional de Investigaciones Científicas y Técnicas de Argentina (CONICET) and Consejo de Investigaciones de la Provincia de Córdoba, Argentina (CONICOR). We thank S. Winter, H. J. Vetten, J. Cohen, and G. Thottappilly for suggestions and gifts of antisera, R. Suasnábar for technical assistance in the greenhouse, and D. Ducasse for his valuable suggestions and critical opinions during the work.

\section{LITERATURE CITED}

1. Alvarez, V., Ducasse, D. A., Biderbost, E., and Nome, S. F. 1997. Sequencing and characterization of the coat protein and 3' non-coding region of a new sweet potato potyvirus. Arch. Virol. 142:1635-1644.

2. Biderbost, E., Castellano, P., Williams, L., Di Feo, L., and Nome, F. 1998. A model for the expression of the "chlorotic dwarf" in agamic progenies of sweet potato plants. Fitopatologia 33:18. (Abstr. in Spanish)

3. Brunt, A. A., Crabtree, K., Dallwitz, M. J., Gibbs, A. J., and Watson, L. 1996. Viruses of Plants. Descriptions and Lists from the VIDE Database. CAB International, Kew, England.

4. Clark, M. F., and Adams, A. N. 1977. Characteristics of the microplate method of enzyme linked immunosorbent assay for the detection of plant viruses. J. Gen. Virol. 34:475-483.

5. Clark, C. A., and Moyer, J. W. 1988. Compendium of Sweet Potato Diseases. The American Phytopathology Society, St. Paul, MN.

6. Cohen, J., Franck, A., Vetten, H. J., Lesemann, D. E., and Loebenstein, G. 1992. Purification and properties of closterovirus-like particles associated with a whitefly-transmitted disease of sweet potato. Ann. Appl. Biol. 121:257-268.

7. Cohen, J., Salomon, R., and Loebenstein, G. 1988. An improved method for purification of sweet potato feathery mottle virus directly from sweet potato. Phytopathology 78:809-811.

8. Di Feo, L., Biderbost, E., Racca, R., Nome, S., Mollinedo, V., and Lopez-Lambertini, P. 1995. Effect of ontogeny and chlorotic dwarf, a viral disease, on the productivity of sweet potato (Ipomoea batatas (L.) Lam.) cv. Morada-INTA. Fitopatologia 30:96-99.

9. Di Feo, L., and Nome, S. F. 1990. Chlorotic dwarf: A new sweet potato disease in Argentina. Newsl. Int. Working Group Sweet Potato Viruses (IWGSPV) No. 3.

10. Fuentes, S. 1994. Preliminary identification of a sweetpotato virus (C-6). Fitopatologia 29: 38. (Abstr. in Spanish)

11. Fuentes, S., Arellano, J., and Meza, M. A. 1997. Preliminary studies of a new virus, C- 8 , affecting sweetpotato. Fitopatologia 32:9-10. (Abstr. in Spanish)

12. Fuentes, S., and Salazar, L. F. 1992. Identification of a new sweetpotato virus. Fitopatologia 27:50. (Abstr. in Spanish)

13. Girardeau, J. H. 1958. The sweet potato whitefly, Bemisia inconspicua Q., as a vector of a sweet potato mosaic in South Georgia. Plant Dis. Rep. 43:819.

14. Hahn, S. K. 1979. Effects of viruses (SPVD) on growth and yield of sweet potato. Exp. Agric. 15:1-5

15. Hahn, S. K., Terry, E. R., and Leuschner, K. 1981. Resistance of sweet potato to virus complex (SPVD). HortScience 16:535-537.

16. Hildebrand, E. M. 1958. Two syndromes caused by sweet potato viruses. Science 128:203-204.

17. Hoyer, U., Maiss, E., Jelkmann, W., Lesemann, D.-E., and Vetten, H. J. 1996. Identification of the coat protein gene of a sweet potato sunken vein closterovirus isolate from Kenya and evidence for a serological relationship among geographically diverse closterovirus isolates from sweet potato. Phytopathology 86:744-750.

18. Jordan, R. 1992. Potyviruses, monoclonal antibodies, and antigenic sites. Arch. Virol. (suppl. 5):81-95.

19. Jordan, R., and Hammond, J. 1991. Comparison and differentiation of potyvirus isolates and identification of strain-, virus-, subgroupspecific and potyvirus group-common epitopes using monoclonal antibodies. J. Gen. Virol. 72: 25-36.

20. Karyeija, R. F., Gibson, R. W., and Valkonen, J. P. T. 1998. The significance of sweet potato feathery mottle virus in subsistence sweet potato production in Africa. Plant Dis. 82:4-15.

21. Kennedy, G. G., and Moyer, J. M. 1982. Aphid transmission and separation of two strains of sweet potato feathery mottle virus from sweet potato. J. Econ. Entomol. 75:130-133.

22. Lizarraga, C., and Fernandez-Northcote, E. N 1989. Detection of potato viruses $\mathrm{X}$ and $\mathrm{Y}$ in sap extracts by a modified indirect enzymelinked immunosorbent assay on nitrocellulose membranes (NCM-ELISA). Plant Dis. 73:1114.

23. López, D., and Salazar, L. F. 1987. Studies on sweet potato feathery mottle virus (SPFMV) in Peru. Fitopatologia 22:40-41. (Abstr. in Spanish)

24. Milne, R. G., and Lesemann, D. E. 1978. An immunoelectron microscopic investigation of oat sterile dwarf and related viruses. Virology 90:299-304.

25. Moyer, J. W. 1986. Variability among strains of SPFMV. (Abstr.) Phytopathology 76:1126.

26. Moyer, J. W., and Kennedy, G. G. 1978. Purification and properties of sweet potato feathery mottle virus. Phytopathology 68:998-1004.

27. Moyer, J. W., and Salazar, L. F. 1989. Viruses and viruslike diseases of sweet potato. Plant Dis. 73:451-455.

28. Nome, S. F. 1973. Sweet potato vein mosaic virus in Argentina. Phytopathol. Z. 77:44-54.

29. Nome, S. F., and Docampo, D. 1974. Incidencia del virus del mosaico de las nervaduras (sweet potato vein mosaic virus) en rendimientos en batata. Pages 1-6 in: IDIA-INTA No. 315-316.

30. Nome, S. F., Giorda, L. M., and Vázquez, A. 1980. El virus del moteado plumoso de la batata (sweet potato feathery mottle virus) en $\mathrm{Ar}$ gentina. Pages 625-634 in: Rev. Invest. Agropecuarias. Vol. 15, no. 4. INTA, Buenos Aires, República Argentina.

31. Parent, J. G., Berlanger, F., Desjardins, S., and Brisson, J. D. 1985. Dot-immunobinding for detection of tomato mosaic virus and potato virus $\mathrm{X}$, infecting greenhouse tomatoes. Phyto- 
protection 66:53-57

32. Pio-Ribeiro, G., Winter, S., Hamilton, R. I., de Assis Filho, F. M., and da Paz, C. D. 1994. First report of sweet potato virus disease-associated closterovirus in Brazil. Plant Dis. 78: 1122.

33. Rossel, H. W., and Thottappilly, G. 1985. Virus diseases of important food crops in tropical Africa. Pages 10-13 in: Sweet Potato. International Institute of Tropical Agriculture, Ibadan, Nigeria.

34. Rossel, H. W., and Thottappilly, G. 1988. Complex virus diseases of sweet potato. Pages 291302 in: Exploration, Maintenance and Utiliza- tion of Sweet Potato Genetic Resources. Rep. 1st Sweet Potato Planning Conf. International Potato Center, Lima, Peru.

35. Salazar, L. F. 1994. Importancia del diagnóstico de virus de plantas. Fitopatología 29:116-118.

36. Shaefers, G. A., and Terry, E. R. 1976. Insect transmission of sweet potato disease agents in Nigeria. Phytopathology 66:642-645.

37. Sheffield, F. M. L. 1957. Virus diseases of sweet potato in East Africa. I. Identification of the viruses and their insect vectors. Phytopathology 47:582-590.

38. Vetten, H. J., Hoyer, U., Maiss, E., Lesemann, D. E. and Jelkmann, W. 1996. Serological detection and discrimination of geographically diverse isolates of sweet potato sunken vein closterovirus. (Abstr.) Phytopathology 86 (suppl.):S100.

39. Winter, S., Purac, A., Leggett, F., Frison, E. A. Rossel, H. W., and Hamilton, R. I. 1992. Partial characterization and molecular cloning of a closterovirus from sweet potato infected with the sweet potato virus disease complex from Nigeria. Phytopathology 82:869-875.

40. Wisler, G. C., Duffus, J. E., Liu, H.-Y., and Li, R. H. 1998. Ecology and epidemiology of whitefly-transmitted closterovirus. Plant Dis. 82:270280. 